\title{
PENGARUH KINERJA MANAJER INVESTASI TERHADAP RETURN REKSADANA SAHAM SYARIAH DI INDONESIA (PERIODE 2011-2015)1)
}

\author{
Siti Zulva Rafika \\ Mahasiswa Program Studi Ekonomi Islam-Fakultas Ekonomi dan Bisnis-Universitas Airlangga \\ Email: siti.zulfa-12@feb.unair.ac.id \\ Nisful Laila \\ Departemen Ekonomi Syariah-Fakultas Ekonomi dan Bisnis-Universitas Airlangga \\ Email: nisful.laila@feb.unair.ac.id
}

\begin{abstract}
:
This research aims to find out the influence of stock selection and market timing toward the return of Islamic mutual funds of stock in Indonesia. This study used seven samples of Islamic mutual funds of stock in Indonesia were obtained using purposive sampling. The stock selection and market timing were counted using Treynor Mazuy Model. The approach used in this study is quantitative approach using double regressions. In analyzing the data, the technique used is panel data regression analysis by using Eviews 8 software. The result of this study shows that in the partially test, the stock selection is proven to have significant influence toward the return of Islamic Mutual Funds of Stock in Indonesia, and the market timing also has significant influence toward the return of Islamic Mutual Funds of Stock. The simultaneously test shows that stock selection and market timing significantly influence the return of Islamic Mutual Funds of Stock.
\end{abstract}

Keywords : Stock Selection, Market Timing, Return of Islamic Mutual Fund of Stock, Treynor Mazuy Model

\section{PENDAHULUAN}

\section{Latar Belakang}

Investasi pada sektor keuangan pada saat ini menjadi sebuah cara dari masyarakat pemodal untuk mengelola dan mengembangkan dana yang mereka miliki. Investasi tersebut bisa dilakukan melalui pasar modal yang merupakan tempat terjadinya transaksi jual beli efek antar para pihak (individu, korporasi, maupun pemerintah). Efek yang dimaksud disini adalah efek dengan jangka waktu panjang. Wiyanti (2012) menjelaskan bahwa

"investasi menurut pandangan Islam sendiri merupakan salah satu kerangka kegiatan muamalah di bidang ekonomi dengan mengacu pada hukum-hukum dan ketentuan syariat Islam".

Islam mendorong umatnya untuk melakukan investasi guna menjaga dan mengembangkan hartanya dengan jalan sesuai dengan kaidah-kaidah hukum Islam. Dengan berinvestasi, harta yang dimiliki menjadi lebih produktif dan bermanfaat bagi orang lain sehingga tidak terpusat atau dikuasai oleh beberapa golongan saja.

Salah satu instrumen investasi pasar modal yang hingga saat ini banyak diminati oleh masyarakat pemodal atau para investor adalah reksadana. Produk ini merupakan salah satu bentuk investasi dengan diversifikasi yang cukup baik dan menawarkan tingkat return atau keuntungan yang cukup tinggi. Melalui reksadana, modal dari para investor

1) Jurnal ini merupakan bagian dari Skripsi yang ditulis oleh Siti Zulva Rafika, NIM:041211431157, yang diuji pada tanggal 7 Juni 2016 
dikumpulkan untuk selanjutnya dibelikan efek oleh manajer investasi. Dengan menanamkan dana milik kolektif itu kedalam berbagai objek investasi (portofolio) maka risiko investasi dapat dikurangi.

Industri reksadana syariah merupakan salah satu segmen yang cepat berkembang didalam sistem keuangan Islam. Reksadana syariah sendiri menjadi alternatif pilihan investasi bagi para investor yang menginginkan dananya ditempatkan atau diinvestasikan pada sektor yang berbasis syariah. Prinsip pokok yang membedakan antara reksadana syariah dengan reksadana konvensional yaitu dalam pengelolaan portofolio investasinya, pada reksadana syariah tidak hanya mempertimbangkan return dari investasinya saja, melainkan juga mempertimbangkan kehalalan dari instrument yang akan diinvestasikan.

Pengertian reksadana syariah sesuai dengan Fatwa DSN MUI No. 20/DSNMUI/IX/2001 adalah reksadana yang beroperasi menurut ketentuan dan prinsip syariah Islam, baik dalam bentuk akad antara pemodal sebagai pemilik harta dengan manajer investasi, maupun antara manajer investasi dengan pengguna investasi (Hamzah dan Yohanes, 2014).

Hingga saat ini reksadana telah menjadi produk investasi yang semakin diminati oleh masyarakat karena telah mampu memberikan return yang relatif besar. Akan tetapi ternyata masih banyak reksadana yang belum menyediakan profil risiko dan tingkat pengembalian (return) secara transparan sehingga hal tersebut membuat para investor masih kesulitan dalam menentukan reksadana mana yang mempunyai kinerja baik dan sesuai dengan preferensi risiko mereka. Disamping itu, kendala lain yang dihadapi oleh investor dalam memilih reksadana yang memiliki kinerja baik yaitu kendala dalam hal kecukupan modal, ketersediaan waktu serta pengetahuan pengelolaan portofolio. Profil dan kinerja portofolio perlu mendapatkan perhatian agar investor tidak terjerumus dengan hanya melihat return yang dihasilkan. Untuk membantu investor menghadapi berbagai kendala tersebut maka diperlukan adanya peran dari manajer investasi yang memiliki kemampuan untuk menciptakan skala ekonomis dalam berinvestasi serta kemampuan yang profesional dalam hal analisis sekuritas serta selalu berusaha mendapatkan hasil investasi terbaik.

Dalam mengelola suatu portofolio manajer investasi dapat menggunakan strategi pasif dan strategi aktif. Strategi pasif merupakan strategi yang tidak memerlukan analisis saham selama periode saham itu dipegang. Sedangkan strategi aktif merupakan strategi dimana manajer investasi akan melakukan tindakan-tindakan aktif dan proaktif terhadap keputusan investasi dengan secara aktif mencari informasi dan melakukan peramalan-peramalan terhadap perilaku pasar ataupun nilai tukar berdasarkan informasi yang 
diperolehnya (Tandelilin, 2010:516). Strategi aktif ini dilakukan dengan menggunakan kemampuan yang dimiliki manajer investasi yaitu kemampuan memilih sekuritas (stock selection) dan kemampuan pengukuran waktu pasar (market timing).

Menurut Sari dan Purwanto (2012) menjelaskan bahwa indikator-indikator yang dapat digunakan untuk menilai kinerja reksadana saham salah satunya yaitu kinerja manajer investasi dengan melihat kemampuan memilih saham (stock selection skill) dan market timing ability serta tingkat risiko dari investasi reksadana. Kemampuan memilih saham (stock selection) menurut Tandelilin (2010:517) adalah kemampuan manajer investasi dalam memilih dan membentuk suatu portofolio invetasi agar portofolio tersebut mampu mendatangkan return atau imbal hasil yang tinggi seperti yang diharapkan oleh investor. Sedangkan market timing merupakan strategi aktif dari manajer investasi dengan melakukan tindakan diantaranya yaitu manajer investasi secara aktif mengamati pergerakan harga dan nilai tukar pasar serta mengambil keputusan untuk memperoleh keuntungan dari pergerakan harga tersebut. Manajer investasi dalam hal ini tentunya akan membeli saham yang nilai intrisiknya di atas harga pasar (undervalued) dan menjual saham-saham yang nilai intrinsiknya dibawah harga pasar (overvalued).

Melalui tindakan tersebut diharapkan bisa memberikan manfaat yaitu memperoleh keuntungan dari perubahan harga saham yang terjadi. Market timing yang tepat dalam pembelian instrumen investasi juga merupakan faktor yang penting selain pemilihan sekuritas dalam meningkatkan kinerja reksadana, sehingga hal tersebut akan menghasilkan excess return yang tinggi.

\section{LANDASAN PUSTAKA}

Menurut Huda dan Heykal (2010:251) menyimpulkan bahwa:

Reksadana Syariah adalah reksadana yang pengelolaan dan kebijakan investasinya berpedoman pada syariah Islam atau tidak bertentangan dengan prinsip-prinsip syariah. Portofolionya hanya berinvestasi pada instrumen yang sesuai dengan syariah, yaitu bebas dari unsur maysir, gharar, dan riba. Reksadana Syariah tidak menginvestasikan dananya pada perusahaan yang pengelolaan dan produknya bertentangan dengan syariat Islam.

Dari ketiga definisi tersebut dapat disimpulkan bahwa reksadana syariah merupakan reksadana yang kriterianya sesuai dengan ketentuan undang-undang pasar modal dan prinsip syariah Islam yang dapat diketahui dari fatwa DSN MUI.

Menurut Hasbi (2010) menjelaskan terdapat 4 jenis reksadana yang berbasis syariah, antara lain:

1. Reksadana syariah saham, yaitu reksadana yang menginvestasikan dananya ke efek syariah bersifat ekuitas. Menurut Farid (2014) menjelaskan bahwa jenis reksadana ini menawarkan imbal hasil yang tertinggi jika dibandingkan reksadana lainnya. Tentunya, imbal hasil yang tinggi ini 
juga diimbangi oleh tingkat resiko yang cukup tinggi.

2. Reksadana syariah campuran, yaitu reksadana yang menempatkan investasi dalam efek syariah bersifat ekuitas dan hutang. Seperti yang dijelaskan Farid (2014) bahwa "reksadana syariah campuran dapat melakukan investasi pada efek hutang maupun efek modal dan porsi alokasi yang lebih fleksibel". Reksadana jenis ini lebih aman pada kondisi pasar dimana terjadi volatilitas yang cukup tinggi dikarenakan investasi di tempatkan diberbagai instrumen, baik itu saham, obligasi, maupun pasar vang.

3. Reksadana syariah pendapatan tetap, yaitu reksadana yang menawarkan imbal hasil terendah jika dibandingkan beberapa reksadana lainnya. Namun, tingkat resiko yang ditawarkan juga rendah. Menurut Farid (2014) menjelaskan bahwa Reksadana Syariah Pendapatan Tetap melakukan investasi minimal $80 \%$ dalam efek bersifat hutang dan $20 \%$ dapat dikelola untuk instrument lainnya.

4. Reksadana Syariah Terproteksi, yaitu reksadana yang memberikan proteksi sebesar $100 \%$ dari nilai investasi awal dengan syarat dan ketentuan khusus yang berlaku. Menurut Farid (2014) menjelaskan bahwa jenis reksadana terproteksi untuk investasi awal investor dilindungi oleh manajer, dengan tujuan supaya tidak berkurang nilainya pada saat jatun tempo. Reksadana ini cenderung diinvestasikan pada instrumen pasar modal dan pasar uang yang lebih aman. Reksadana terproteksi berusaha melindungi nilai pokok investasi investor dengan cara melakukan strategi pasif yaitu dengan membeli obligasi dan memegangnya hingga jatuh tempo.

Sudarsono (2004:201) menyatakan bahwa

"Net Assset Value (NAV) atau nilai aktiva bersih (NAB) merupakan alat ukur kinerja reksadana. Nilai aktiva bersih berasal dari nilai portofolio reksadana. Aktiva atau kekayaan reksadana bisa dilihat pada kas, deposito, saham, obligasi, dan surat berharga lainnya".

Soemitra (2009:188) menjelaskan total nilai aktiva bersih pada periode tertentu dapat dihitung menggunakan rumus :

Total $N A B=$ Nilai aktiva - Total kewajiban

Nilai aktiva bersih per unit :

NAB Per Unit = Total nilai aktiva bersih

Total unit penyertaan (saham) diterbitkan Dimana:

Total $N A B=$ Jumlah Nilai Aktiva Bersih pada periode tertentu

NAB Per Unit = Nilai Aktiva Bersih per saham atau unit penyertaan pada periode tertentu.

Nilai Aktiva Bersih digunakan untuk menghitung return suatu reksadana. Return realisasi merupakan return yang telah terjadi. Return realisasi dapat dihitung melalui data histories (Jogiyanto, 2010:205). Hamzah dan Yohanes (2014) menjelaskan bahwa return realisasi dapat diukur dengan menggunakan rumus sebagai berikut: 
$R i=\frac{N A B_{t}-N A B_{t-1}}{N A B_{t-1}}$

Dimana :

Ri $\quad=$ Tingkat pengembalian portofolio

$\mathrm{NAB}_{\dagger}=$ Nilai aktiva bersih pada akhir periode $t$

$\mathrm{NAB}_{t-1}=$ Nilai aktiva bersih pada awal periode $t$

Swinkels (2003) menjelaskan bahwa komponen return reksadana terdapat dua variabel yang mempengaruhi adalah Manager skill yang terdiri dari selectivity dan Market timing. Menurut Tandelilin (2010:516) manajer investasi dapat berusaha untuk meningkatkan kinerja reksadana yang dikelolanya dengan melakukan strategi aktif, yaitu dengan memiliki kemampuan stock selection dan market timing.

Stock Selection merupakan proses untuk memilih sekuritas yang akan dibeli atau ditahan pada tiap-tiap kelas sekuritas yang telah ditentukan. Menurut Tandelilin (2010:517) menjelaskan bahwa yang dilakukan manajer investasi disini adalah menentukan sekuritas-sekuritas apa saja yang akan dipilih dari pasar yang telah ditentukan dalam keputusan alokasi aset dengan tujuan untuk mengoptimalkan return yang diperoleh dari suatu pasar.

Aspek kedua selain stock selection yang membentuk kinerja portofolio adalah pengukuran waktu pasar (market timing). Market timing yang tepat dalam pembelian instrumen investasi juga merupakan faktor yang penting selain pemilihan sekuritas dalam meningkatkan kinerja reksadana.

Menurut Waelan (2008) menjelaskan bahwa

"Market timing merupakan kemampuan manajer investasi untuk melakukan penyesuaian portofolio asset guna mengantisipasi perubahan atau pergerakan harga pasar secara umum".

Untuk dapat mengetahui kemampuan stock selection dan market timing dari Manajer Investasi dapat digunakan Model Treynor-Mazuy. Model persamaan Treynor Mazuy dapat melihat besaran alfa (a) yang menunjukkan kemampuan memilih saham. Jika manajer memiliki (a > 0) berarti manajer investasi memiliki kemampuan memilih saham yang baik dan sebaliknya jika $(a<0)$ artinya kemampuan yang dimiliki manajer investasi tidak baik. Menurut Jensen (1968) menjelaskan bahwa "alfa (a) sebagai ukuran kinerja (measure of performane) portofolio dari kemampuan pemilihan sekuritas oleh manajer investasi, sehingga alfa (a) juga menggambarkan rata-rata peningkatan imbal hasil portofolio per waktu yang berasal dari kemampuan manajer investasi dalam memprediksi harga sekuritas".

Sedangkan nilai $Y$ menunjukkan kemampuan market timing yang dimiliki manajer investasi. Jika nilai $Y>0$ maka seorang manajer investasi memiliki kemampuan market timing, semakin besar nilai $Y$ maka semakin besar pula kemampuan yang dimiliki oleh manajer investasi (Treynor dan Mazuy, 1966 dalam Gumilang dan Subiyantoro, 2008). 
Rafika, et al/Jurnal Ekonomi Syariah Teori dan Terapan Vol. 4 No. 3 Maret 2017: 219-234; PENGARUH KINERJA MANAJER INVESTASI TERHADAP RETURN REKSADANA SAHAM SYARIAH DI INDONESIA (PERIODE 2011-2015)

Hamzah dan Yohanes (2014) menjelaskan persamaan Treynor Mazuy sebagai berikut:

$R_{p t}-R_{f t}=a_{p}+\beta_{p}\left(R_{m t}-R_{f t}\right)+Y_{p}\left(R_{m t}-R_{f t}\right)^{2}$

$+\varepsilon_{\mathrm{p} t}$

Dimana :

$\mathrm{R}_{\mathrm{pt}} \quad=$ return portofolio pada periode $\dagger$

$\mathrm{Rft}_{\mathrm{ft}} \quad=$ risk free return pada periode $\dagger$

$a_{p} \quad=$ abnormal return yang menggambarkan stock selection

$\beta_{p} \quad=$ koefisien dari market return $\left(R_{m t}\right)$ dikurangi risk free rate $\left(\mathrm{R}_{\mathrm{ft}}\right)$

$\mathrm{Y}_{\mathrm{p}}=$ koefisien yang menggambarkan kemampuan market timing

Ept $\quad=$ kesalahan acak

Komponen-komponen perhitungan dalam mencari nilai stock selection dan market timing dengan menggunakan Treynor Mazuy Model antara lain:

1. Tingkat Return Reksadana Saham Syariah

Return adalah "hasil investasi (capital gain) yang dinyatakan dalam persentase modal awal dan ditambah dividen yang diterima. Capital gain adalah selisih positif antara harga jual dikurangi harga beli" (Samsul, 2006:370). Dalam penelitian ini menggunakan tingkat pengembalian (return) reksadana syariah yang diteliti dengan rentang waktu penelitian sejak bulan Januari 2011 sampai Desember 2015. Hasil perhitungan tingkat actual return didasarkan atas perhitungan tingkat return bulanan sepanjang tahun 20112015. Actual return penting karena digunakan sebagai salah satu pengukur kinerja dari perusahaan.

1. Tingkat pendapatan bebas risiko
Tingkat pendapatan bebas risiko merupakan tingkat pendapatan yang diterima dari instrumen bebas risiko. Menurut Widoatmodjo (2007:125) menjelaskan Instrumen bebas risiko memiliki ciri-ciri antara lain: 1) penghasilan investasi sudah pasti diterima investor contoh: deposito bank, 2) biasanya diterbitkan oleh pemerintah misalnya SBI dan SBIS. SBIS menjadi acuan tingkat pendapatan bebas risiko (Rf) untuk Reksadana Saham Syariah. Untuk mengetahui rata - rata Rf dalam satu tahun digunakan rumus:

$R f=R f_{n}: 12$

Keterangan:

$\mathrm{Rf}=$ rata-rata risk free rate

$\mathrm{Rf}_{\mathrm{n}}=$ risk free rate periode ke-n

12 = jumlah bulan dalam satu tahun

2. Tingkat Pendapatan Pasar (Return Market)

Samsul (2006:373) menjelaskan pengertian pendapatan pasar yaitu

"perubahan indeks pasar yang dinyatakan dalam persentase, yaitu indeks pasar sekarang dibandingkan dengan indeks pasar kemarin, atau indeks pasar bulan ini dibandingkan dengan indeks pasar bulan lalu, dan perubahannya dinyatakan dalam persentase".

Pendapatan pasar merupakan suatu indikator tingkat pengembalian yang diberikan oleh pasar, dimana digunakan Indeks Harian JII (Jakarta Islamic Index) untuk dijadikan patokan atau market benchmark. Perhitungan pasar dapat dilakukan dengan persamaan sebagai berikut:

$R_{m t}=\left(I H S J\left\|_{\dagger}-\mid H S J\right\|_{t-1}\right):\|H S J\|_{t-1}$ 
Rafika, et al/Jurnal Ekonomi Syariah Teori dan Terapan Vol. 4 No. 3 Mare t2017: 219-234; PENGARUH KINERJA MANAJER INVESTASI TERHADAP RETURN REKSADANA SAHAM SYARIAH DI INDONESIA (PERIODE 2011-2015)

Dimana :

$\mathrm{R}_{\mathrm{mt}} \quad$ = Pendapatan pasar dari JII

pada periode $\dagger$

IHSJII+

= Nilai indeks Jll pada akhir periode $\dagger$

$|H S J| I_{-1}$

= Nilai indeks Jll pada akhir periode $\mathrm{t}^{-1}$

\section{Hipotesis}

Hipotesis yang diambil dalam penelitian ini adalah:

Hipotesis 1 : Stock selection dan market timing secara simultan berpengaruh signifikan terhadap return Reksadana Saham Syariah di Indonesia.

Hipotesis 2 : Stock selection secara parsial berpengaruh signifikan terhadap return Reksadana Saham Syariah di Indonesia.

Hipotesis 3 : Market timing secara parsial berpengaruh signifikan terhadap return Reksadana Saham Syariah di Indonesia

\section{Model Analisis}

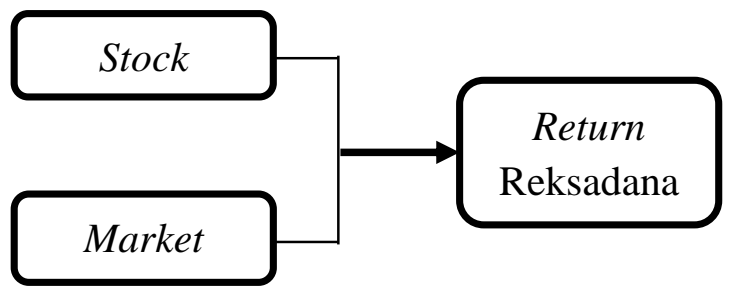

Sumber: Data Diolah

\section{Gambar 1.}

Model Analisis

Pada gambar 1. dijelaskan bahwa model analisis untuk melihat kinerja Reksadana Saham Syariah terdapat indikator yang perlu dijadikan pertimbangan yaitu mengenai kinerja manajer investasi. Penilaian terhadap kinerja manajer investasi dilakukan dengan melihat kemampuan stock selection skill dan market timing ability dengan melakukan analisis regresi berganda menggunakan Treynor Mazuy Model untuk mendapatkan alpha (a) yang menunjukkan kemampuan stock selection dan gamma (Y) yang menunjukkan kemampuan market timing manajer investasi pada masing-masing reksadana saham syariah. Kemudian untuk mengetahui pengaruh stock selection dan market timing terhadap return Reksadana Saham Syariah menggunakan regresi linear berganda.

\section{METODOLOGI PENELITIAN}

\section{Pendekatan Penelitian}

Penelitian ini menggunakan pendekatan kuantitatif yang bertujuan untuk menguji hipotesis. Menurut Anshori dan Iswati (2009:13) menjelaskan bahwa pendekatan kuantitatif merupakan suatu metode penelitian yang mengkuantitatifkan data dan menerapkan satu bentuk analisis untuk menerima atau menolak hipotesis. Analisis uji hipotesis (hypotheses testing) dalam penelitian ini bertujuan untuk menguji hipotesis yang diajukan peneliti serta untuk mengetahui hubungan antar variabel yang didasarkan pada hipotesis yang sebelumnya telah peneliti kemukakan. Hubungan antar variabel yang dimaksud dalam penelitian ini adalah untuk mengetahui pengaruh stock selection dan market timing secara simultan dan secara parsial terhadap return Reksadana Saham Syariah di Indonesia. Teknik analisis yang 
digunakan dalam penelitian ini adalah teknik analisis regresi data panel dengan menggunakan software Eviews 8.

\section{Identifikasi Variabel}

Untuk menjawab rumusan masalah dan menguji hipotesis, maka variabel yang digunakan dalam penelitian ini adalah stock selection dan market timing yang diukur dengan menggunakan Treynor Mazuy Model dan return Reksadana Saham Syariah.

\section{Definisi Operasional Variabel}

Untuk memberikan gambaran yang jelas mengenai variabel yang digunakan dalam penelitian ini, maka variabel tersebut dapat didefinisikan sebagai berikut:

\section{Stock Selection}

Stock selection merupakan proses untuk memilih sekuritas yang akan dibeli atau ditahan pada tiap-tiap kelas sekuritas yang telah ditentukan. Menurut Tandelilin (2010:517) menjelaskan bahwa yang akan dilakukan manajer investasi adalah menentukan sekuritas-sekuritas apa saja yang akan dipilih dari pasar yang telah ditentukan dalam keputusan alokasi aset dengan tujuan untuk mengoptimalkan return yang diperoleh dari suatu pasar.

\section{Market Timing}

Market timing merupakan strategi aktif manajer investasi dengan melakukan tindakan diantaranya yaitu manajer investasi secara aktif mengamati pergerakan harga dan nilai ukar pasar serta mengambil keputusan untuk memperoleh keuntungan dari pergerakan harga tersebut (Tandelilin, 2010:517). Manajer investasi dalam hal ini akan membeli saham yang nilai intrinsiknya diatas harga pasar (undervalued) dan menjual saham-saham yang nilai intrinsiknya dibawah harga saham (overvalued). Melalui tindakan tersebut diharapkan bisa memberikan manfaat yaitu memperoleh keuntungan dari perubahan harga saham yang terjadi.

3. Return Reksadana

Menurut Samsul

(2006:370)

menjelaskan bahwa

"Return merupakan hasil investasi atau capital gain yang dinyatakan dalam persentase modal awal dan ditambah dividen yang diterima. Sedangkan capital gain merupakan selisih positif antara harga jual dikurangi harga beli" (Samsul, 2006:370).

Tingkat pengembalian (return) reksadana syariah yang diteliti dengan rentang waktu penelitian sejak Januari 2011 sampai Desember 2015.

Hasil perhitungan tingkat actual return didasarkan atas perhitungan tingkat return bulanan sepanjang tahun 20112015. Actual return penting karena digunakan sebagai salah satu pengukur kinerja dari perusahaan. Perhitungan return dilakukan secara bulanan, sehingga untuk mendapatkan nilai return dalam satu tahun menggunakan persamaan:

Return dalam satu tahun = Total return bulanan dalam satu tahun

\section{Jenis dan Sumber Data}

Dalam penelitian ini, keseluruhan datanya adalah data sekunder yang diperoleh dari Statistik Reksadana Syariah yang diterbitkan di ojk.go.id dan 
Rafika, et al/Jurnal Ekonomi Syariah Teori dan Terapan Vol. 4 No. 3 Maret 2017: 219-234; PENGARUH KINERJA MANAJER INVESTASI TERHADAP RETURN REKSADANA SAHAM SYARIAH DI INDONESIA (PERIODE 2011-2015)

pusatdata.kontan.com untuk mendapatkan Nilai Aktiva Bersih yang diambil periode 1 Januari 2011- 31 Desember 2015. Data Index Harian JII (Jakarta Islamic Index) sebagai tolak ukur pasar diperoleh dari situs www.duniainvestasi.com. Selain itu data tingkat imbal hasil SBIS sebagai tolak ukur aset bebas resiko (risk free rate) yang diperoleh dari situs Bank Indonesia yaitu wWw.bi.go.id.

\section{Populasi dan Sampel}

Sampel yang digunakan dalam penelitian ini dilakukan dengan metode purpose sampling yang berarti bahwa teknik pengambilan sampel bersifat tidak acak dimana sampel dipilih berdasarkan pertimbangan tertentu. Ketentuan yang ditetapkan oleh peneliti untuk memilih sampel adalah sebagai berikut:

1. Reksadana Saham Syariah yang telah beroperasi aktif selama periode penelitian yaitu 1 Januari 2011 - 31 Desember 2015.

2. Reksadana Saham Syariah yang terdaftar dalam OJK (otoritas jasa keuangan) yang beroperasi aktif selama periode penelitian.

3. Sampel adalah jenis reksadana saham yang menginvestasikan sekurang-kurangnya $\quad 80 \% \quad$ dari aktivanya berbentuk ekuitas.

4. Reksadana yang diteliti selama periode penelitian tidak sedang dalam kondisi dilikuidasi, tidak merger, dan tidak bubar.

5. Sampel yang diambil merupakan produk dari jenis reksadana syariah saham yang Nilai Aktiva Bersihnya dipublikasikan di media cetak minimal Januari 2011.

Berdasarkan kriteria tersebut, dari 25 populasi Reksadana Saham Syariah didapatkan sampel sebanyak 7 Reksadana Saham Syariah.

\section{Teknik Analisis}

Menurut Ajija, dkk (2011:51) menjelaskan bahwa terdapat 3 macam pendekatan dalam menganalisa data panel, yaitu Common Effect Model, Fixed Effect Model dan Random Effect Model. Berikut adalah pengertian dari ketiga model tersebut:

1. Common Effect Model /Pool Least Square (PLS)

Model common effect merupakan pendekatan data panel yang paling sederhana. Model ini tidak memperhatikan dimensi individu maupun waktu sehingga diasumsikan bahwa perilaku antar individe sama dalam berbagai kurun waktu. Model ini hanya mengkombinasikan data time series dan cross section dalam bentuk pool.

2. Model Fixed effect

Model ini mengasumsikan bahwa terdapat efek yang berbeda antar individu. Perbedaan itu dapat dikombinasikan melalui perbedaan pada intersepnya. Teknik model fixed effect adalah teknik mengestimasi data panel dengan menggunakan variabel dummy untuk menangkap adanya perbedaan intersep. Pengertian fixed effect ini didasarkan adanya perbedaan intersep 
Rafika, et al/Jurnal Ekonomi Syariah Teori dan Terapan Vol. 4 No. 3 Maret 2017: 219-234; PENGARUH KINERJA MANAJER INVESTASI TERHADAP RETURN REKSADANA SAHAM SYARIAH DI INDONESIA (PERIODE 2011-2015)

antara perusahaan, namun intersepnya sama antar waktu.

3. Random Effect Model (Error Component Model)

Model random effect ini menggunakan variabel gangguan (error terms). Model ini mengestimasi data panel dimana variabel gangguan mungkin saling berhubungan antar waktu dan antar individu.

Untuk menentukan teknik yang paling tepat dalam mengestimasi regresi data panel, terdapat beberapa pengujian yang dilakukan. Pertama adalah uji statistik F (Uji Chow) yang digunakan untuk memilih antara metode CEM atau FEM. Pengambilan keputusan uji chow didasarkan dari nilai probabilitas, dimana jika $p$-value $>0,05$ maka penggunaan metode CEM lebih baik daripada metode FEM. Yang kedua adalah uji Hausman yang digunakan untuk memilih antara metode FEM atau REM. Pengambilan keputusan juga didasarkan dari nilai probabilitas, dimana jika $p$-value $>0,05$ maka metode CEM lebih baik dari FEM.

Metode panel memiliki beberapa keunggulan yang mana keunngulan tersebut dapat meminimalkan bias yang mungkin ditimbulkan oleh agregasi data individu. Keunggulan-keunggulan tersebut memiliki implikasi pada tidak harus dilakukan pengujian asumsi klasik dalam model data panel (Verbeek (2000); Gujarati (2003); Wibisono (2005); Aulia (2004:27) dalam Ajija (2011:52)).

\section{Uji Hipotesis}

Uji F

Uji $F$ bertujuan untuk mengetahui pengaruh semua variabel independen dalam satu model regresi terhadap variabel dependen. Pengujian dilakukan dengan menggunakan significance level 0,05 ( $a=5 \%$ ). Apabila signifikansi $<0,05$, maka $\mathrm{H}_{0}$ ditolak atau secara simultan semua variabel independen berpengaruh secara signifikan terhadap variabel dependen.

Uji $t$

Uji $†$ dilakukan untuk membuktikan apakah variabel independen secara individu mempengaruhi variabel dependen. Pengujian dilakukan dengan menggunakan significance level 0,05 $(a=5 \%)$. Apabila signifikansi $<0,05$, maka $\mathrm{H}_{0}$ ditolak atau secara parsial variabel independen berpengaruh secara signfikan terhadap variabel dependen. Sebaliknya, bila signifikansi > 0,05 maka $\mathrm{H}_{0}$ diterima atau secara parsial variabel independen berpengaruh tidak signifikan terhadap variabel dependen.

\section{Koefisien Determinasi}

Koefisien determinasi $\left(R^{2}\right)$ digunakan untuk mengukur persentase total variasi variabel dependen yang dapat dijelaskan oleh variabel independen dalam garis regresi.

\section{Hasil dan Pembahasan}

\section{Analisis Model}

Uji Chow merupakan pengujian untuk memilih kedua model diantara Model Commond Effect (CEM) dan Fixed Effect Model (FEM). 
Tabel 1.

Hasil Perhitungan Uji Chow

\begin{tabular}{lcrc}
\hline \hline Effects Test & Statistic & d.f. & Prob. \\
\hline \hline Cross-section F & 0.798664 & $(6,26)$ & 0.5797 \\
Cross-section Chi-square & 5.920525 & 6 & 0.4322 \\
\hline \hline
\end{tabular}

Sumber: Data Diolah

Berdasarkan tabel 1. menunjukkan bahwa nilai probabilitas (Cross-section F) sebesar 0,5797 atau dengan kata lain nilai prob. cross-section lebih besar dari a $(0,05)$ sehingga dapat disimpulkan bahwa model yang lebih tepat digunakan adalah Common Effect Model dengan kata lain tidak perlu dilakukan uji Hausman.

Tabel 2.

Output Eviews 8 Estimasi Data Panel dengan Metode CEM

Dependent Variable: $Y$

Method: Panel Least Squares

Date: 04/07/16 Time: $11: 55$

Sample: 20112015

Periods included: 5

Cross-sections included: 7

Total panel (balanced) observations: 35

\begin{tabular}{lrlll}
\hline \hline \multicolumn{1}{c}{ Variable } & Coefficient & Std. Error & t-Statistic & Prob. \\
\hline \hline C & 5.708748 & 1.716749 & 3.325325 & 0.0022 \\
X2 & 12.37057 & 1.834126 & 6.744668 & 0.0000 \\
& 115.0945 & 30.25590 & 3.804034 & 0.0006 \\
\hline \hline R-squared & 0.588149 & Mean dependent var & 3.414219 \\
Adjusted R-squared & 0.562408 & S.D. dependent var & 14.92702 \\
S.E. of regression & 9.874333 & Akaike info criterion & 7.499571 \\
Sum squared resid & 3120.078 & Schwarz criterion & 7.632887 \\
Log likelihood & -128.2425 & Hannan-Quinn criter. & 7.545591 \\
F-statistic & 22.84901 & Durbin-Watson stat & 2.846174 \\
Prob(F-statistic) & 0.000001 & & & \\
\hline \hline
\end{tabular}

Sumber: Data Diolah

Uji F

Berdasarkan tabel 2. diketahui tingkat probabilitas (F-statistic) sebesar 0,000001 yang lebih kecil dari 0,05 . Berarti $\mathrm{H}_{0}$ ditolak dan $H_{1}$ diterima, berdasarkan hasil tersebut maka dapat disimpulkan bahwa variabel independen (stock selection dan market timing) secara simultan berpengaruh signifikan terhadap variabel dependen yaitu return Reksadana Saham Syariah di Indonesia.

Tabel 3.

Output EViews 8 Hasil Uji F

\begin{tabular}{|c|c|}
\hline F-statistic & 22,84901 \\
\hline Prob(F-statistic) & 0.000001 \\
\hline
\end{tabular}

Sumber: Data Diolah

Uji $\uparrow$

Berdasarkan tabel 2. maka dapat dilakukan pembahasan terhadap masingmasing variabel sebagai berikut:

1. Pengaruh Stock Selection terhadap return Reksadana Saham Syariah

Pengujian ini dilakukan untuk melihat signifikansi pengaruh stock Selection terhadap Return Reksadana Saham Syariah di Indonesia. Berdasarkan tabel 2. diketahui bahwa probabilitas stock selection yaitu sebesar 0,0000 yang lebih kecil dari 0,05. Maka dapat disimpulkan bahwa variabel stock selection secara parsial berpengaruh signifikan terhadap return Reksadana Saham Syariah di Indonesia.

2. Pengaruh Market Timing terhadap return Reksadana Saham Syariah

Pengujian ini bertujuan untuk melihat signifikansi pengaruh market timing terhadap return Reksadana Saham Syariah di Indonesia. Berdasarkan tabel 2. diketahui bahwa probabilitas market timing sebesar 0,0006 yang lebih kecil dari 0,05 . Maka dapat disimpulkan bahwa market timing secara parsial berpengaruh signifikan terhadap return Reksadana Saham Syariah di Indonesia. 
Tabel 4.

Output Eviews 8 Hasil Uji $t$

\begin{tabular}{|c|c|c|}
\hline Variable & t-Statistic & Prob. \\
\hline Stock Seletion & 6.744668 & 0.0000 \\
\hline Market timing & 3.804034 & 0.0005 \\
\hline
\end{tabular}

Sumber: Data Diolah

\section{Koefisien Determinasi}

Koefisien determinasi berganda

bertujuan untuk mengukur seberapa jauh kemampuan variabel independen dalam menjelaskan variabel dependen (Ghozali, 2011 :97). Nilai yang mendekati satu berarti variabel-varaibel independen memberikan hampir semua informasi yang dibutuhkan untuk memprediksi variabel dependen. Berdasarkan tabel ditunjukkan nilai hasil $R$ Square yaitu 0,562408 atau sebesar $56,24 \%$ yang artinya variabel independen yaitu stock selection dan market timing dapat menjelaskan variabel dependen yaitu return Reksadana Saham Syariah sebesar 56,24\%, sedangkan sisanya yaitu $43,76 \%$ dijelaskan oleh variabel-variabel lain diluar variabel yang digunakan dalam penelitian ini seperti kebijakan alokasi aset. Pada penelitian yang dilakukan oleh Nurcahya (2010) menyebutkan bahwa tingkat risiko reksadana tergantung pada kebijakan alokasi aset yang artinya bagaimana manajer investasi mengalokasikan dananya pada kelas-kelas aset yang tersedia dan seberapa besar porsi pendistribusian dananya sehingga hal tersebut juga akan mempengaruhi kinerja ataupun return dari reksadana.
Tabel 5.

Output Eviews 8 Hasil Koefisien Determinasi

\begin{tabular}{|c|c|}
\hline R-Squared & Adjusted R-Squared \\
\hline 0.588149 & 0.562408 \\
\hline
\end{tabular}

Sumber: Data Diolah

\section{Pembahasan}

Pengaruh Stock Selection dan Market Timing tehadap Return Reksadana Saham Syariah

Berdasarkan uji F-statistik yang telah dilakukan, dapat dikatakan bahwa secara simultan stock selection dan market timing berpengaruh terhadap return Reksadana Saham Syariah di Indonesia. Hal ini berarti menerima hipotesis pertama $\left(\mathrm{H}_{\mathrm{al}}\right)$ bahwa stock selection dan market timing berpengaruh terhadap retun Reksadana Saham Syariah di Indonesia.

Stock selection adalah strategi dengan tindakan secara aktif melakukan analisis dan memilih saham-saham dengan kategori baik atau yang disebut superior. Saham superior yang dimaksud disini yaitu saham-saham yang memberikan hubungan tingkat return dan risiko yang terbaik dibandingkan alternatif lainnya. Tindakan tersebut dilakukan dengan tujuan untuk dapat meningkatkan return harapan investor.

Manajer investasi mempunyai kewajiban untuk melaksanakan investasi bagi kepentingan investor sesuai dengan kontrak yang ada. Sedangkan, untuk bank kustodian berkewajiban untuk menyimpan, menjaga dan mengawasi dana investor dan menghitung Nilai Aktiva Bersih (NAB) per unit penyertaan dalam 
dana reksa syariah. Atas pemberian jasa dalam pengelolahan investasi dan penyimpanan dana kolektif tersebut, manajer investasi dan bank kustodian berhak memperoleh imbal jasa yang dihitung atas presentase yang telah disepakati dari nilai NAB reksadana syariah pada saat kontrak awal ditandatangani. Dan apabila dalam hal manajer investasi atau bank kustodian tidak melaksanakan amanah dari investor sesuai dengan kewenangan yang diberikan atau manajer investasi dan bank kustodian dianggap lalai, maka manajer investasi dana atau bank kustodian bertanggung jawab atas resiko yang ditimbulkannya.

Hasil penelitian ini menunjukkan bahwa dalam melakukan investasi pada Reksadana Saham Syariah seorang investor harus mempertimbangkan beberapa aspek yang salah satunya yaitu mengenai kemampuan dari manajer inevstasi. Begitu pula dengan manajer investasi dituntut untuk mampu memilih komposisi saham mana saja yang mampu memberikan keuntungan yang paling maksimal, serta mampu melakukan peramalan waktu yang tepat sehingga return reksadana yang dihasilkan mampu memberikan hasil yang maksimal.

Pentingnya menilai kinerja manajer investasi sangat dianjurkan dalam Islam. Hal tersebut dibahas dalam Al -Qur'an surat Al Qashash ayat 26 sebagai berikut:

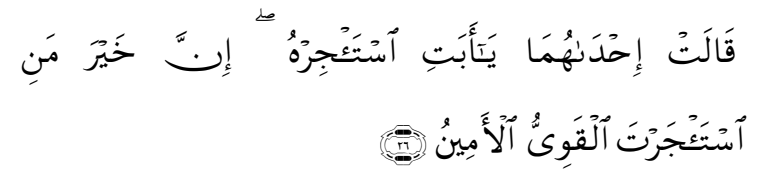

qālat 'ịndāhumā yā-'abati sta 'jirhu 'inna khayra mani sta 'jarta l-qawiyyu l- 'aminu Artinya: " salah seorang dari kedua wanita itu berkata: "Ya bapakku ambillah ia sebagai orang yang bekerja (pada kita), karena Sesungguhnya orang yang paling baik yang kamu ambil untuk bekerja (pada kita) ialah orang yang kuat lagi dapat dipercaya." (Q.S. 28:26, Departemen Agama Rl, 2010:310)

Pada ayat tersebut dijelaskan tentang seseorang yang menyewa jasa (tenaga) dari orang lain untuk bekerja. Namun, ada beberapa syarat yang harus dipenuhi seperti orang itu harus kuat (dewasa) dan dapat dipercaya. Islam mengajak setiap orang agar selektif dalam memilih orang yang akan bertanggung jawab dalam masalah harta, mulai tahap pengumpulannya, pembelanjaannya, penginvestasiannya, maupun pengaturan dalam bentuk apapun.

Cara yang perlu diperhatikan sesuai dengan anjuran Islam menurut ayat tersebut yaitu dengan memilih orangorang yang siap untuk diajak bekerja sama, menunjuk para pengelola yang mempunyai kapabilitas dan mempunyai integritas moral yang tinggi, serta berlaku amanah. Dengan cara demikian, akan terwujud kematangan dalam manajemen harta yang akan berimbas pada kemaslahatan dan dapat memberikan manfaat kepada sesamanya.

\section{Pengaruh Stock Selection terhadap Return}

\section{Reksadana Saham Syariah}

Pengaruh stock selection secara parsial terhadap return Reksadana Saham Syariah dapat dilihat dari hasil uji hipotesis t yang meyatakan bahwa stock selection 
secara parsial berpengaruh signifikan terhadap return Reksadana Saham Syariah di Indonesia periode 2011-2015.

Hasil penelitian ini juga mendukung hasil penelitian Nurcahya (2010) tentang Analisis Kebijakan Alokasi Aset, Pemilihan Saham dan Tingkat Risiko terhadap Kinerja Reksadana Saham di Indonesia Periode 2006-2008. Pada penelitian tersebut menggunakan model Treynor Mazuy sebagai alat ukur untuk menghitung pemilihan saham (stock selection). Hasil penelitian nya menyatakan bahwa variabel pemilihan sekuritas (stock selection) berpengaruh positif dan signifikan terhadap kinerja reksadana syariah sehingga kemampuan pemilihan saham yang tepat mampu memberikan imbal hasil yang tinggi.

Penelitian yang dilakukan oleh Low (2007) bertolak belakang dengan hasil penelitian ini. Penelitian tersebut dilakukan dengan menggunakan reksadana di Malaysia dengan judul Malaysian Unit Trust Funds' Performance During Up and Down Market Conditions. Sampel pada penelitian tersebut yaitu menggunakan 40 Reksadana di Malaysia dengan periode penelitian selama 5 tahun, yaitu pada Januari tahun 1996 sampai Desember tahun 2000. Sedangkan untuk menilai kinerja reksadana digunakan model Jensen, dan untuk mengukur kinerja manajer investasi yang meliputi stock selection dan market timing digunakan model Henrikson Merton. Hasil penelitian yang didapatkan yaitu stock selection berpengaruh tidak signifikan terhadap return reksadana, sehingga hasil penelitian yang dilakukan oleh Low (2007) tersebut bertolak belakang dengan hasil penelitian ini.

\section{Pengaruh Market Timing terhadap Return Reksadana Saham Syariah}

Hasil pengujian hipotesis menunjukkan bahwa market timing secara parsial berpengaruh signifikan terhadap return Reksadana Saham Syariah.

Market timing merupakan strategi aktif dari manajer investasi dengan melakukan tindakan diantaranya yaitu manajer investasi secara aktif mengamati pergerakan harga dan nilai tukar pasar serta mengambil keputusan untuk memperoleh keuntungan dari pergerakan harga tersebut. Manajer investasi dalam hal ini tentunya akan membeli saham yang nilai intrisiknya di atas harga pasar (undervalued) dan menjual saham-saham yang nilai intrinsiknya dibawah harga pasar (overvalued). Melalui tindakan tersebut diharapkan bisa memberikan manfaat yaitu memperoleh keuntungan dari perubahan harga saham yang terjadi.

Hasil penelitian ini bertolak belakang dengan penelitian yang dilakukan oleh Nurcahya (2010) yang meniliti tentang pengaruh kebijakan alokasi aset, kinerja manajer investasi dan tingkat risiko terhadap kinerja reksadana saham. Dalam penelitian tersebut variabel kinerja kinerja manajer investasi mengabaikan market timing dan hanya menggunakan variabel stock selection saja. Hal tersebut dikarenakan kemampuan market timing 
sangat sulit dilakukan sehingga hanya mengandalkan kemampuan stock selection atau pemilihan sekuritas dari manajer investasi.

\section{SIMPULAN}

Berdasarkan analisis dan pembahasan yang telah dilakukan, maka simpulan dari penelitian ini adalah:

1. Secara simultan stock selection dan market timing berpengaruh secara signifikan terhadap return Reksadana Saham Syariah. Hal ini menunjukkan bahwa untuk meningkatkan return Reksadana Saham Syariah maka harus mempertimbangkan kemampuan manajer investasi yang meliputi stock selection dan market timing.

2. Terdapat pengaruh secara signifikan stock selection terhadap return Reksadana Saham Syariah. Artinya semakin tinggi nilai stock selection maka nilai dari return Reksadana Saham Syariah akan semakin tinggi pula.

3. Terdapat pengaruh yang signifikan market timing terhadap return Reksadana Saham Syariah. Artinya, semakin tinggi nilai market timing maka nilai dari return Reksadana Saham Syariah juga akan semakin tinggi.

\section{DAFTAR PUSTAKA}

Ajija, Shochrul R., Dyah W. Sari, Rahmat H. Setianto, Martha R. Primanti. 2011. Cara Cerdas Menguasai Eviews. Jakarta: Salemba Empat.
Anshori, Muslich dan Sri Iswati. 2009. Buku Ajar Metodologi Penelitian Kuantitatif. Surabaya: Pusat Penerbitan dan Percetakan Unair.

Departemen Agama RI. 2010. Al-Qur'an dan Terjemahannya. Surabaya: Pustaka Assalam.

Farid, Muhammad. 2014. Mekanisme dan Perkembangan Reksadana Syariah. latishoduna, Vol. 4 No. 1 Hal: 61-72

Ghozali, Imam. 2011 . Aplikasi Analisis Multivariate dengan Program IBM SPSS19. Edisi5. Semarang: Badan Penerbit Unversitas Diponegoro.

Gumilang, T.F dan Subiyantoro H. 2008. "Reksadana Pendapatan Tetap di Indonesia: Analisis Market Timing dan Stock selection -Periode 2006-2008

Hamzah, Amal dan Agustinus Yohanes. 2014. Analisis Perbandingan Kinerja Reksadana Syariah dengan Reksadana Konvensional Jenis Saham pada Periode 2008-2012. Jurnal MIX, IV (3): 396-409

Hasbi, Hariandy. 2010. Kinerja Reksadana Syariah Tahun 2009 di Indonesia. Jurnal Keuangan dan Perbankan, 14 (1): 62-73

Huda, Nurul dan Mohamad Heykal. 2010. Lembaga Keuangan Islam. Jakarta: Kencana Prenada Media Group

Jensen, M. 1968. The Performance of Mutual funds in the Period 1945-1964. Journal of Finance, Vol. 23, pp. 389-416

Jogiyanto, Hartono. 2010, Teori Portofolio dan Analisis Investasi, Yogyakarta: BPFE Yogyakarta.

Low, Soo-Wah. 2007. Malaysian Unit Trust Funds' Performance During Up and Down Market Conditions: A Comparison of Market Benchmark. Managerial Finance, 33 (2): 154-166

Nurcahya, Ginting Prasetiya Enka. 2010. Analisis Kebijakan Alokasi aset, Pemilihan Saham dan Tingkat Risiko Terhadap Kinerja Reksadana Saham di Indonesia. Surakarta: Universitas Sebelas Maret

Samsul, Mohamad. 2006. Pasar Modal dan Manajemen Portofolio. Jakarta: Erlangga.

Sari, Anindita Putri Nurmalita \& Agus Purwanto. 2012. Analisis Kebijakan Alokasi Aset, Kinerja Manajer Invetasi dan Tingkat Risiko Terhadap Kinerja Reksadana Saham di Indonesia. 
Diponegoro Journal Of Accounting, 1 (1): 1-14

Soemitra, Soemitra. 2009. Bank dan Lembaga Keuangan Syariah. Jakarta : Kencana Prenada Media Group.

Sudarsono, Heri. 2004. Bank dan Lembaga Keuangan Syariah Deskripsi dan llustrasi. Yogyakarta: EKONISIA

Swinkels, Laurens dan Sluis, Peter J. Van. 2003. Market Timing: A Decomposition of Mutual Fund Returns. Erasmus Research Institute of Management, Report Series Research In Management, pp 1-39

Tandelilin, Eduardus. 2010. Portofolio dan Investasi. Yogyakarta: Kanisius.

Waelan. 2008. Kemampuan Memilih Saham dan Market Timing Manajer Investasi Reksadana Saham di Brusa Efek Indonesia. JAAl, 12 (2): 167-176

Wiroatmodjo, Sawidji. 2007. Seri Membuat Uang Bekerja untuk Anda Panduan Mempraktikkan Rich Dad, Poor Dad: Cara Benar Mencapai Puncak Kemakmuran Finansial $\bar{A}$ la Robert $T$. Kiyosaki. Jakarta: PT. Elex Media Komputindo

Wiyanti, Diana. 2012. Perspektif Hukum Islam terhadap Pasar Modal Syariah Sebagai Alternatif Invetasi Bagi Investor. Jurnal HUkUm IUS QUIA IUSTUM, 2 (20): 234-254

www.bapepam.go.id (diakses pada 21 Agustus 2015)

www.bi.go.id (diakses pada 23 Maret 2016)

www.ojk.go.id (diakses pada 21 Agustus 2015)

www.duniainvestasi.com (diakses pada 15 Desember 2015)

www.pusatdatakontan.com (diakses pada 15 Desember 2015) 